ISSN: 2146-3042

DOI: $10.25095 /$ mufad.607225

\title{
Muhasebe Meslek Mensuplarının Mesleki Tükenmişlik Düzeylerinin Araştırılması: Bursa İli Örneği*
}

\author{
Tuba BORA KILINÇARSLAN** \\ Rüyam KÜÇÜKSÜLEYMANOĞLU***
}

\section{$\ddot{O Z Z T T}$}

Tükenmişlik sendromu, iş stresine bağlı olarak ortaya çıkan ve insan ilişkilerinin yoğun olduğu iş ortamlarında etkisini daha fazla gösteren bir olgudur. Bu çalışmanın amacı, Bursa Serbest Muhasebeci Mali Müşavirler Odası'na kayıtl muhasebe meslek mensuplarının tükenmişlik düzeylerini araştırmak ve tükenmişlik düzeylerinin demografik değişkenlere göre farklılık gösterip göstermediğini tespit etmektir. Çalışmada tükenmişlik ölçeği olarak, 3 alt boyuttan (duygusal tükenme, duyarsızlaşma, kişisel başarı) oluşan 22 maddeli Maslach Tükenmişlik Ölçeği kullanılmıştır. 391 muhasebe meslek mensubunun katıldı̆̆ bu araştırmaya ilişkin veriler SPPS 23 paket programında analiz edilmiş, tükenmişlik düzeylerinin demografik değişkenlere göre farklılık gösterip göstermediğini tespit etmek amacıla $t$ testi ve ANOVA testi uygulanmıştır. Araştırma sonucunda muhasebe meslek mensuplarının yüksek düzeyde tükenmişlik yaşadığı; tükenmişlik düzeylerinin alt boyut/boyutlarının cinsiyete, yaşa, eğitim durumuna, medeni duruma, mevcut iş yerindeki çalışma süresine ve mesleki çalışma süresine göre istatistiksel olarak anlaml farklılık gösterdiği; çalışma yeri ve çalışma şekline göre farklılık göstermediği tespit edilmiştir.

Anahtar Kelimeler: Mesleki tükenmişlik, muhasebe meslek mensupları, Maslach Tükenmişlik Ölçeği

JEL Sinıflandırması: M40, M41.

\section{An Empirical Research on the Professional Burnout Levels of Accountants: The} Case of Bursa Province

\section{ABSTRACT}

Burnout syndrome is a fact that occurs depending on the work stress and shows its effect more in working environments where long-term work in human services. The aim of this study is to investigate the burnout levels of accountants registered with the Bursa Chamber of Certified Public Accountants and to determine whether their burnout levels differ according to demographic variables. In the study, 22 items Maslach Burnout Inventory was used consisting of 3 sub-dimensions (emotional exhaustion, depersonalization, personal accomplishment). The sample of the study was formed 391 accountants. The data were analyzed in SPPS 23 package program and $t$ test and ANOVA test were applied to determine whether burnout levels differed according to demographic variables. As a result of the research, accountants experienced high levels of burnout; that the sub-dimensions of burnout levels showed statistically significant differences according to gender, age, educational status, marital status, working time in current work place and professional working time; it was determined that it did not differ according to the working place and working style.

Keywords: Professional Burnout, Accountants, Maslach Burnout Inventory.

Jel Classification: M40, M41.

Makale Gönderim Tarihi: 01.06.2019

Makale Kabul Tarihi: 01.08.2019

Makale Türü: Araştırma Makalesi

\footnotetext{
* Bu çalışma, 1-4 Mayıs 2019 tarihleri arasında Bursa'da düzenlenen V. Uluslararası Muhasebe ve Finans Sempozyumu'nda özet bildiri olarak sunulmuştur.

** Ress. Assisttant., Bursa Uludağ Üniversitesi, İktisadi ve İdari Bilimler Fakültesi, tubabora@uludag.edu.tr, ORCID ID: 0000-0001-9258-3829

*** Associate Prof.., Bursa Uludağ Üniversitesi, Eğitim Fakültesi, ruyamk@uludag.edu.tr
} 


\section{GíRiş}

Çalışma ortamlarında iş yükünün artmasıyla birlikte aşırı stres ve yoğun iş temposuna maruz kalan çalışanlar, beklentilerinin karşılığını alamadığı zaman tatminsizlik yaşamakta ve işe karşı isteksiz olma eğilimine girmektedirler. $\mathrm{Bu}$ durum çalışanların motivasyonunu düşürmekte ve iş performansını etkilemektedir. İş hayatında yaşanan bu problemler çalışanların tükenmesine neden olabilmektedir.

Devlet ile mükellef arasındaki bağlantıyı sağlayan, vergi ile ilgili ödevlerin yerine getirilmesinde aracı olarak sorumluluk üstlenen muhasebe meslek mensupları yoğun iş yükü altında iş yetiştirme stresiyle karşı karşıya kalabilmektedir. Stres altında çalışan muhasebe meslek mensuplarının hata yapma olasılıkları artmakta ve buna bağlı olarak muhasebe meslek mensupları cezai yaptırımlara maruz kalabilmektedir. Ayrıca mücbir sebep durumlarında bile (meslek mensubunun doğum yapması veya ağır hastalığı, yakınlarının ölümü vb.) mesleki görevlerini yerine getirmek zorunda kalmaları muhasebe meslek mensuplarını tükenmişliğe doğru itmektedir.

Ulusal ve uluslararası literatür incelendiğinde; sağlık çalışanları, öğretmenler, akademisyenler gibi farklı meslek gruplarının tükenmişlik düzeylerinin araştırıldığı birçok çalışmaya rastlamak mümkündür. Muhasebe meslek mensuplarının mesleki tükenmişlik düzeylerinin araştırılması da çeşitli çalışmalara konu olmuş ve özellikle 2000'li yıllardan itibaren artış göstermiştir. Ersoy ve Utku (2005), Ay ve Avşaroğlu (2010), Doğan ve Nazlıoğlu (2010), Guthrie ve Jones (2012), Taysı (2012), Okutan vd. (2013), Deran ve Beller (2015), Yanık ve Yanık (2016), Kotan (2016), Stowe (2016), Öz ve Çeviren (2017), Öztürk vd. (2009), Temelli ve Şendurur (2018) muhasebe meslek mensuplarının mesleki tükenmişlik düzeylerinin demografik değişkenlere göre (yaş, cinsiyet, eğitim durumu, mesleki deneyim vb.) farklılık gösterip göstermediğini araştırırken; Fogarty vd. (2000), Sweeney ve Summers (2002), Çiftçioğlu (2011), Öztürk vd. (2011), Uyar ve Erdinç (2011), Özkan ve Özdevecioğlu (2013), Dalğar ve Tekşen (2014), Hacıhasanoğlu ve Karaca (2014), Karakaş ve Bilen (2014), Gürel ve Gürel (2015), Çelik (2016), Günay ve Demiralay (2016), Demir ve Sezgin (2017), Tepeli vd. (2017), İl (2018) muhasebe meslek mensuplarının mesleki tükenmişlik düzeylerinin çeşitli konularla (iş tatmini, yaşam doyumu, işe bağlılık, örgütsel bağl1lık, iş/işgören performansı, rol stres modelleri, iş stresi, iş yükü, işten ayrılma niyeti vb.) olan ilişkilerini incelemişlerdir.

Muhasebe meslek mensuplarının dışında muhasebe ve finans alanında çalışanların mesleki tükenmişlik düzeylerinin araştırıldığı çalışmalar da mevcuttur. Sılığ (2003), Haque ve Aslam (2011), Khattak vd. (2011), Güllüce ve Kaygın (2013), Belias vd. (2013), Kasap vd. (2013), Gürbüz ve Karapınar (2014), Karapınar ve Gürbüz (2015) banka çalışanlarının mesleki tükenmişliklerini araştırırken; Kalbers ve Fogarty (2005), Kingori (2007), Larson (2011), Herda ve Lavelle (2012), Utami ve Nahartyo (2013), Cannon ve Herda (2016) denetçilerin; Eker ve Anbar (2008), Byrne vd. (2013) muhasebe ve finans alanında çalışan akademisyenlerin mesleki tükenmişliklerine ilişkin çalışmalarda bulunmuşlardır.

$\mathrm{Bu}$ çalışmanın amacı, ülkemizin üye sayısı (yaklaşık 5.000) bakımından dördüncü büyük muhasebe meslek odası olan Bursa Serbest Muhasebeci Mali Müşavirler Odası'na (Bursa SMMMO) kayıtlı muhasebe meslek mensuplarının tükenmişlik düzeylerini araştırmak 
ve tükenmişlik düzeylerinin demografik değişkenlere göre farklılık gösterip göstermediğini tespit etmektir.

\section{TÜKENMIŞLIKK KAVRAMI VE BOYUTLARI}

Tükenmişlik kavramı, ilk kez H. J. Freudenberger'in 1974 yılında yayımladığ 1 "Staff Burn-Out" adlı makalesi ile literatüre girmiştir. Freudenberger (1974) tükenmişliğgi; kronik iş stresi nedeniyle duygusal tükenmeye, motivasyon kaybına ve mesleki başarı düşüklüğüne neden olan psikolojik bir sendrom olarak tanımlamaktadır. Pines vd. (1981) göre tükenmişlik, insan ilişkilerin yoğun olduğu ortamlarda uzun süreli çalışmaya bağlı olarak ortaya çıkan kronik veya tekrarlanan duygusal baskıların bir sonucudur. Diğer bir ifadeyle tükenmişlik, ara sıra yaşanan olaylardan ziyade kronik stres ile ilişkilidir ve iş stresi ile başa çıkamama olarak tanımlanmaktadır (Felton, 1998). Maslach (2003) ise tükenmişliği, işyerindeki stres artırıcı unsurlara karşı bir tepki olarak uzun sürede ortaya çıkan psikolojik bir sendrom olarak ifade etmektedir. Görüldüğü üzere tükenmişlik kavramına ilişkin literatürde farklı tanımlar yer almakla beraber, en yaygın şekilde tükenmişlik, "duygusal talepler gerektiren durumlara uzun süre maruz kalmanın neden olduğu fiziksel, duygusal veya zihinsel tükenme hali” olarak tanımlanmaktadır (Schaufeli ve Greenglass, 2001:501).

Uluslararası literatürde tükenmişlik kavramını açıklamak için üç teorik model sıklıkla kullanılmaktadır. Bunlardan birincisi Maslach ve Jackson (1981) tarafından geliştirilen model, ikincisi Golembiewski vd. (1986) tarafından geliştirilen model, üçüncüsü ise Lee ve Ashforth (1996) tarafından geliştirilen modeldir. Maslach modelinde tükenmişlik, duygusal tükenme ile başlayıp, duyarsızlaşmaya ve daha sonra kişisel başarının azalmasına neden olmakta iken; Golembiewski vd. modelinde tükenmişlik duyarsızlaşma ile başlamaktadır. Lee ve Ashforth modelinde ise, Maslach modelindeki gibi duygusal tükenme duyarsızlaşmanın temelini oluştururken, kişisel başarının azalması doğrudan duygusal tükenmeden kaynaklanmakta, duyarsızlaşmadan bağımsız olarak gelişmektedir (Bährer-Kohler, 2013:3-4). Üç modelden de anlaşılacağı üzere, tükenmişliğin duygusal tükenme, duyarsızlaşma ve kişisel başarı olmak üzere üç alt boyutu bulunmaktadır.

Duygusal tükenme, tükenmişliğin bireysel stres boyutunu temsil etmekte ve bireyin duygusal ve fiziksel kaynaklarında tükenmesini ifade etmektedir. Duyarsızlaşma, tükenmişliğin kişiler arası boyutunu temsil etmekte ve hizmet verilenlere karşı negatif, katı tutumları ve kişinin işine karşı tepkisiz olmasını ifade etmektedir. Düşük kişisel başarı ise, tükenmiş̧liğin öz değerlendirme boyutunu temsil etmekte ve bireyin işinde kendisini başarısız ve verimsiz hissetmesini ifade etmektedir. (Maslach vd., 2001:399).

Tükenmişlik düzeyini ölçmek için ise Maslach Tükenmişlik Envanteri (MBI), ShiromMelamed Tükenmişlik Ölçeği (SBMQ), Copenhagen Tükenmişlik Envanteri (CBI), Oldenburg Tükenmişlik Envanteri (OLBI), Spanish Tükenmişlik Envanteri (SBI) gibi çeşitli ölçekler kullanılmaktadır. Bunlardan özellikle hizmete dayalı mesleklerde en yaygın olarak kullanılanı, yirmi iki maddeli üç alt boyutlu Likert ölçeğindeki Maslach Tükenmişlik Envanteri'dir. Bu envanterin alt boyutlarında elde edilen puanlar Tablo 1'deki gibi yorumlanmaktadır: (Maslach ve Jackson, 1986) 
Tablo 1. Tükenmişlik Puanları

\begin{tabular}{lccc}
\hline \multirow{2}{*}{ Tükenmişlik Alt Boyutları } & \multicolumn{3}{c}{ Tükenmişlik Düzeyleri } \\
\cline { 2 - 4 } & Düşük & Orta & Yüksek \\
\hline Duygusal Tükenme (DT) & $\leq 16$ & $17-26$ & $\geq 27$ \\
\hline Duyarsızlaşma (D) & $\leq 6$ & $7-12$ & $\geq 13$ \\
\hline Kişisel Başarı (KB) & $\geq 39$ & $32-38$ & $\leq 31$ \\
\hline
\end{tabular}

Tablo 1'den de görüldügü üzere, duygusal tükenme ve duyarsızlaşma alt boyutlarından elde edilen ortalama puanlar yükseldikçe tükenmişlik düzeyi artmakta olup, kişisel başarı alt boyutundan elde edilen ortalama puanlar yükseldikçe tükenmişlik düzeyi azalmaktadır.

\section{LITERATÜR ARAȘTIRMASI}

Ülkemizde farklı illerde faaliyet gösteren muhasebe meslek mensuplarının tükenmişlik düzeylerinin demografik değişkenlere göre farklılık gösterip göstermediğini araştıran çeşitli çalışmalar bulunmaktadır. Bu çalışmalardan bazıları aşağıdaki gibi özetlenebilir:

Ay ve Avşaroğlu (2010), Türkiye'nin çeşitli bölgelerinde faaliyet gösteren 1494 muhasebe çalışanı (mali müşavir, mali müşavir stajyeri, serbest muhasebeci ve muhasebe elemanı) üzerinde yaptıkları çalışmada; tükenmişlik düzeylerinin duygusal tükenme boyutunda cinsiyet ve yaşa göre farklılık gösterdiğini, duyarsızlaşma ve kişisel başarı boyutunda hizmet sürelerine göre farklılık gösterdiğini, çalışanların bölgeleri, çalışma biçimleri, gelir düzeyi ve iş yeri türünün ise tüm alt boyutlarda farklılık gösterdiğini tespit etmişlerdir. Buna göre, muhasebe çalışanları arasında erkeklerin duygusal tükenme düzeylerinin kadınlara göre anlamlı düzeyde yüksek olduğu, Ege bölgesinde faaliyetlerini sürdüren muhasebe çalışanlarının işlerine karşı duyarlılık düzeyleri, duygusal bağ kurma ve başarı algısının daha yüksek olduğu, bağımsız çalışanların bağımlı ve ortak çalışanlara göre tüm alt boyutlarda daha fazla tükenmişlik yaşadığı ve gelir düzeyini düşük olarak algılayan muhasebe meslek mensuplarının daha fazla tükenmişlik yaşadığı sonucuna varmışlardır.

Doğan ve Nazlığlu (2010), Kayseri ilinde faaliyet gösteren 120 muhasebe meslek mensubu üzerinde yaptıkları çalışmada; muhasebe meslek mensuplarının farklı düzeylerde tükenmişlik yaşadığını ve tükenmişlik boyutlarının genellikle orta düzeyde olduğunu, tükenmişlik düzeylerinin tüm alt boyutlarının çocuk sahibi olma durumuna, ünvana, çalışma y1lına ve farklı işte çalışma durumuna göre farklılık göstermediğini, duyarsızlaşma boyutunun cinsiyete, yaşa, eğitim durumuna ve medeni duruma göre farklılık gösterdiğini, kişisel başarı boyutunun ise yaşa ve gelir durumuna göre farklılık gösterdiğini belirtmişlerdir.

Taysı (2012), Kırklareli SMMMO’ya kayıtlı bağımsız çalışan 117 muhasebe meslek mensubu üzerinde yapmış olduğu çalışmada; kadın meslek mensuplarında üç alt boyutta da tükenmişlik düzeyi yüksek iken, erkek meslek mensuplarında duygusal tükenmişlik ve duyarsızlaşma alt boyutlarında tükenmişlik düzeyi orta, kişisel başarı alt boyutunda tükenmişlik düzeyinin yüksek olduğunu tespit etmiştir. 26-35 yaş aralığında olanların, ön lisans mezunlarının, çocuk sahibi olmayanların, aylık 1.500 TL'ye kadar gelir elde edenlerin ve meslekte 1-5 yıl arasında hizmet eden muhasebe meslek mensuplarının tükenmişlik 
düzeyinin yüksek olduğu sonucuna varmıştır. SMMM'lerin tükenmişlik düzeyinin SM'lerden daha yüksek olduğu da araştırma sonuçları arasındadır.

Deran ve Beller (2015), Giresun il merkezinde faaliyet gösteren 34 muhasebe meslek mensubu üzerinde yaptıkları çalışmada; meslek mensuplarının tükenmişlik düzeylerinin yüksek olduğu, tükenmişlik düzeylerinin tüm alt boyutlarının unvan, eğitim düzeyi ve yaş gruplarına göre farklılık göstermediği, cinsiyet ile kişisel başarı alt boyutunda, mesleki deneyim ile duygusal tükenme ve kişisel başarı alt boyutlarında farklılık olduğu sonucuna ulaşmışlardır.

Kotan (2016), Van ilinde faaliyet gösteren 71 muhasebe meslek mensubu üzerinde yaptığı çalışmada; muhasebe meslek mensuplarının tükenmişlik düzeylerinin tüm alt boyutlarda orta düzeyde olduğu sonucuna varmıştır. Medeni durum, yaş ve deneyim ile tükenmişlik düzeylerinin alt boyutları arasında anlamlı bir farklılığa rastlamazken, cinsiyet ve eğitim durumu ile sadece duyarsızlaşma alt boyutu arasında anlamlı bir farka ulaşmıştır. Buna göre, duyarsızlaşma alt boyutunda erkeklerin kadınlara göre ve lise mezunlarının lisans mezunlarına göre tükenmişlik düzeylerinin daha yüksek olduğunu ifade etmiştir.

Yanık ve Yanık (2016), Kocaeli ilinde faaliyet gösteren 400 muhasebe meslek mensubu (SM, SMMM ve YMM) üzerinde yapmış oldukları çalışmada, muhasebe meslek mensuplarının cinsiyet ve medeni durumları ile tükenmişlik düzeylerinin alt boyutları arasında istatistiksel olarak anlamlı bir farka ulaşamamışlardır. Yaş ve aylık gelir düzeyi ile tükenmişlik düzeyinin tüm alt boyutları arasında anlamlı fark bulurlarken; eğitim düzeyi ile duyarsızlaşma ve kişisel başarı alt boyutunda, mesleki deneyim ile duygusal tükenme alt boyutunda, çalışma şekli ile duyarsızlaşma alt boyutunda, unvan ile kişisel başarı alt boyutunda farklılığa ulaşmışlardır. Buna göre, bağımsız çalışan muhasebe meslek mensuplarının bağımlı çalışanlara göre duyarsızlaşma boyutunda daha yüksek tükenmişlik yaşadığı, 50-59 yaş grubunun duygusal tükenme ve duyarsızlaşma boyutunda daha yüksek tükenmişlik yaşadığı, 25 yıl ve üstü deneyime sahip olanların duygusal tükenme boyutunda daha yüksek tükenmişlik yaşadığı elde edilen bulgular arasındadır.

Öz ve Çeviren (2017), Mersin SMMMO’ya kayıtlı 320 muhasebe meslek mensubu üzerinde yapmış oldukları çalışmada, muhasebe meslek mensuplarının duygusal tükenme ve duyarsızlaşma alt boyutunda düşük, kişisel başarı alt boyutunda yüksek düzeyde tükenmişlik yaşadığı sonucuna ulaşmışlardır. Yaş, medeni durum, unvan ve mesleki deneyim ile tükenmişlik düzeylerinin alt boyutlarında anlamlı bir fark tespit edememişlerdir. Kadın muhasebe meslek mensuplarının erkek muhasebe meslek mensuplarına göre duygusal tükenme ve duyarsızlaşma boyutunda daha fazla tükenmişlik yaşadıklarını, erkek muhasebe meslek mensuplarının ise kadın muhasebe meslek mensuplarına göre kişisel başarı alt boyutunda daha fazla tükenmişlik yaşadığı sonucuna ulaşmışlardır. Ayrıca kişisel başarı alt boyutunda çocuğu olmayan grup ile 2 çocuğu olan grup ve 3 ve üzeri sayıda çocuğu olan grup arasında anlamlı farklılık olduğunu, duygusal tükenme alt boyutu bakımından lise mezunu ile lisans mezunu arasında anlamlı farklılık bulunduğunu, duyarsızlaşma alt boyutu bakımından ise ön lisans mezunu ile lisans mezunu arasında anlamlı farklılık bulunduğunu, bağımlı çalışanların duygusal tükenme ve duyarsızlaşma alt boyutlarında daha fazla tükenmişlik yaşadıklarını; bağımsız çalışanların ise kişisel başarı alt boyutunda daha fazla tükenmişlik yaşadıklarını ortaya koymuşlardır. 
Temelli ve Şendurur (2018), TRA1 (Erzurum, Erzincan, Bayburt) ve TRA2 (Kars, Ardahan, Iğdır, Ağrı) bölgelerindeki 199 muhasebe meslek mensupları üzerinde yaptıkları çalışmada; tükenmişliğin üç alt boyutunda da cinsiyete, eğitim durumuna, ünvana ve çocuk sahipliğine göre anlamlı farklılıklar olduğunu; gelir düzeyine ve faaliyette bulunulan ile göre hiçbir boyutta fark olmadığını; yaş ve mesleki deneyime göre duygusal tükenme ve duyarsızlaşma boyutunda farklılıklar olduğunu; medeni durumda ise duygusal tükenme ve kişisel başarı boyutunda farklılıklar olduğunu ortaya koymuşlardır. Buna göre, kadın muhasebe meslek mensuplarının erkek muhasebe meslek mensuplarına göre tüm alt boyutlarda daha fazla tükendiği, 61 ve üzeri yaşta olan muhasebe meslek mensuplarının diğer yaş grubunda olan meslektaşlarından daha fazla duygusal tükenmişlik ve duyarsızlaşma gösterdikleri, boşanmış/dul olan muhasebe meslek mensuplarının evli olan ve bekar olan meslektaşlarına göre daha fazla duygusal tükenmişlik gösterdikleri, evli olan meslek mensuplarının bekâr ve boşanmış/dul meslektaşlarına göre kişisel başarı boyutunda daha fazla tükenmişlik gösterdikleri, ön lisans mezunu olan muhasebe meslek mensuplarının eğitim durumu farklı olan diğer meslektaşlarına göre daha fazla tükenmişlik gösterdikleri, 31 yıl ve üzeri mesleki deneyimine sahip olan meslek mensupların diğer meslektaşlarına göre daha fazla duygusal tükenmişlik ve duyarsızlaşma gösterdikleri, SM unvanlı meslek mensuplarının SMMM unvanlı meslektaşlarına göre daha fazla tükenmişlik gösterdikleri tespit edilmiştir.

\section{ARAŞTIRMA METODOLOJISİ}

\subsection{Araştırmanın Amacı}

$\mathrm{Bu}$ çalışmanın amacı, Bursa Serbest Muhasebeci Mali Müşavirler Odası'na (Bursa SMMMO) kayıtlı muhasebe meslek mensuplarının tükenmişlik düzeylerinin araştırılması ve tükenmişlik düzeylerinin demografik değişkenlere göre farklılık gösterip göstermediğinin tespit edilmesidir. Bu çalışmanın amacı kapsamında aşağıda yer alan araştırma sorularına yanıt aranmaya çalışılacaktır:

- Muhasebe meslek mensuplarının tükenmişlik düzeyleri cinsiyete göre farklllık göstermekte midir?

- Muhasebe meslek mensuplarının tükenmişlik düzeyleri yaşa göre farklılık göstermekte midir?

- Muhasebe meslek mensuplarının tükenmişlik düzeyleri eğitim durumuna göre farklılık göstermekte midir?

- Muhasebe meslek mensuplarının tükenmişlik düzeyleri medeni duruma göre farklılık göstermekte midir?

- Muhasebe meslek mensuplarının tükenmişlik düzeyleri mevcut iş yerindeki çalışma süresine göre farklılık göstermekte midir?

- Muhasebe meslek mensuplarının tükenmişlik düzeyleri mesleki çalışma süresine göre farklılık göstermekte midir?

- Muhasebe meslek mensuplarının tükenmişlik düzeyleri çalışma yerine göre farklılık göstermekte midir?

- Muhasebe meslek mensuplarının tükenmişlik düzeyleri çalışma şekline göre farklılık göstermekte midir? 


\subsection{Verilerin Toplanması}

Çalışmada veri toplama aracı olarak anket yöntemi kullanılmıştır. İki bölümden oluşan anketin birinci bölümünde araştırmaya katılan muhasebe meslek mensuplarına ilişkin kişisel bilgi formu (cinsiyet, yaş, eğitim durumu, medeni durum, mevcut iş yerindeki çalışma süresi, mesleki çalışma süresi, mevcut çalışma yeri ve çalışma şekli) yer almaktadır. Anketin ikinci bölümünde ise, muhasebe meslek mensuplarının tükenmişlik düzeylerini ölçmek için Maslach ve Jackson (1981) tarafindan geliştirilen ve Ergin (1992) tarafindan Türkçeye uyarlanan 3 alt boyutlu (duygusal tükenme, duyarsılaş̧ma, kişisel başarı) 22 maddeli 5'li Likert ölçeğinden oluşan Maslach Tükenmişlik Ölçeği kullanılmıştır. Ölçeğin alt boyutları olan Duygusal Tükenme (DT) boyutu 9 maddeden, Duyarsılzlaşma (D) boyutu 5 maddeden, Kişisel Başarı (KB) boyutu 8 maddeden oluşmaktadır. 5'li Likert ölçeğinde ise " $1=$ Hiçbir zaman, $2=$ Çok nadir, 3=Bazen, 4=Çoğu zaman, 5=Her zaman" seçenekleri yer almaktadır.

Anket, Bursa SMMMO’nun resmi web sitesinde iki ay boyunca yer almış ve online olarak 391 muhasebe meslek mensubu anketi cevaplamıştır.

\subsection{Araştırma Evreni ve Örneklemi}

Araştırmanın evrenini Bursa SMMMO’ya kayıtlı $4943^{1}$ serbest muhasebeci mali müşavir oluşturmaktadır.

Araştırma evreninin bilindiği durumlarda, seçilecek örneklemin büyüklüğü belirlenirken aşağıdaki formülden yararlanılabilmektedir: (Salant ve Dillman, 1994:55)

$$
n=\frac{\mathrm{N} \mathrm{t}^{2} \mathrm{p} \mathrm{q}}{\mathrm{d}^{2}(\mathrm{~N}-1)+\mathrm{t}^{2} \mathrm{p} \mathrm{q}}
$$

Formülde,

$\mathrm{N}=$ Evrendeki birey sayıs

$\mathrm{n}=$ Örnekleme alınacak birey sayıs 1

$\mathrm{p}=$ İncelenecek olayın görülüşs sıklığı (gerçekleşme olasıllığı)

q = İncelenecek olayın görülmeyiş sıklığı (gerçekleşmeme olasıllğı)

$\mathrm{t}=$ Belirli bir anlamlılık düzeyinde, $\mathrm{t}$ tablosuna göre bulunan teorik değer

$\mathrm{d}=$ Olayın görülüş sıklı̆̆ına göre yapılmak istenen + sapma olarak simgelenmiştir.

Formüle göre, \% 95 güven aralığında $\% 5$ hata payı ile araştırmanın görülüşs sıklığ $\%$ 50 olarak belirlendiğinde, örneklem büyüklüğü 357 olarak hesaplanmıştır. Dolayısıyla araştırmaya katılan 391 muhasebe meslek mensubu araştırma evrenini temsil edecek niteliktedir.

\footnotetext{
${ }^{1} 27$ Aralık 2018 tarihi itibariyle Bursa Serbest Muhasebeci Mali Müşavirler Odası’na kayıtlı üye sayısı.
} 


\section{4. Ölçeğin Güvenilirliği}

Ölçeğin güvenilirliği Cronbach alfa katsayısı ile ölçülmüştür. Üç alt boyutun da dahil edildiği Cronbach alfa değeri 0,812 olarak bulunmuştur. Maslach ve Jackson (1981) tarafindan geliştirilen ve Türkçeye uyarlandıktan sonra Ergin (1992) ve Çam (1992) tarafından güvenilirliği sınanan bu ölçeğin, her alt boyutuna ait Cronbach alfa değerleri karş1laştırmalı olarak Tablo 2'de verilmiştir.

Tablo 2. Karşılaştırmalı Cronbach Alfa Değerleri

\begin{tabular}{lcccc}
\hline \multirow{2}{*}{$\begin{array}{c}\text { Tükenmişlik Alt Boyutları ve } \\
\text { Örneklem Sayıları }\end{array}$} & $\begin{array}{c}\text { Maslach } \\
\text { ve Jackson } \\
(1981)\end{array}$ & $\begin{array}{c}\text { Ergin } \\
(1992)\end{array}$ & $\begin{array}{c}\text { Çam } \\
(1992)\end{array}$ & $\begin{array}{c}\text { Bu } \\
\text { çalışmada }\end{array}$ \\
\hline Duygusal Tükenme (DT) & 0.90 & 0.83 & 0.89 & 0.91 \\
\hline Duyarsızlaşma (D) & 0.79 & 0.65 & 0.71 & 0.74 \\
\hline Kişisel Başarı (KB) & 0.71 & 0.72 & 0.72 & 0.78 \\
\hline Örneklem & 1316 & 552 & 276 & 391 \\
\hline
\end{tabular}

Tablo 2'den de görüldüğü üzere, bu çalışmada güvenilirlik katsayıları Duygusal Tükenme boyutunda 0.91, Duyarsızlaşma boyutunda 0.74, Kişisel Başarı boyutunda 0.78 olarak hesaplanmıştır. Ayrıca Tablo 2'ye bakıldığında bu çalışmanın alt boyutlarının güvenilirlik katsayılarının, ölçeğin orijinal halindeki ve Türkçeye uyarlaması yapılan çalışmalardaki güvenilirlik katsayılarına yakın olduğu da görülmektedir.

\subsection{Verilerin Analizi ve Elde Edilen Bulgular}

Muhasebe meslek mensuplarının mesleki tükenmişlik düzeylerinin araştırılmasına ve tükenmişlik düzeylerinin demografik değişkenlere göre farklılık gösterip göstermediğinin tespitine yönelik yapılan bu çalışmada, verilerin analizinde SPSS 23 paket programı kullanılmıştır. Öncelikle araştırmaya katılan muhasebe meslek mensuplarının demografik özelliklerinin sayı ve yüzde dağılımı incelenmiş ve tükenmişlik puanları hesaplanmıştır. Daha sonra araştırmaya katılan muhasebe meslek mensuplarının tükenmişlik düzeylerinin demografik değişkenlere göre farklılık gösterip göstermediğinin tespiti için öncelikle normallik testi yapılmıştır. Veriler normal dağılım gösterdiğinden parametrik testlerden $\mathrm{t}$ testi ve ANOVA testi veri setine uygulanmıştır.

Araştırmaya katılan muhasebe meslek mensuplarının demografik özellikleri Tablo 3'de yer almaktadır. Buna göre araştırmaya katılanların çoğunluğunu $(\% 58,3)$ erkek mali müşavirler oluşturmaktadır. Katılımcıların yaşlarına göre dağılımları incelendiğinde, araştırmaya en çok katılım gösterenler $(\% 38,6)$ 36-45 yaş aralığındadır. Bunu \%30,9'luk bir oranla 25-35 yaş aralığ izlemektedir. En az katılım gösterenler $(\% 9,2)$ ise 56 yaş ve üzerindeki muhasebe meslek mensuplarıdır. Katılımcıların çoğunluğu üniversite mezunu olup, evlidir. Katılımcıların mevcut iş yerindeki çalışma sürelerine bakıldığında, mevcut iş yerinde 1-5 yıl arası ve 21 yıl ve üzeri çalışanlar en çok katılım gösteren grup olup, mevcut iş yerinde 1 yıldan az çalışanlar en az katılım $(\% 7,9)$ göstermiştir. Katılımcıların mesleki kıdemlerinin oldukça yüksek olduğu, yarıya yakın bir katılımın $(\% 43,2) 21$ yıl ve üzeri mesleki deneyime sahip olduğu da görülmüştür. Araştırmaya katılanların çoğunluğu $(\% 66,5)$ SMMM bürosunda çalışmakta olup, \%29,2'si özel sektörde muhasebe departmanlarında 
çalışmakta, çok az bir kısmı da $(\% 4,3)$ bağımsız denetim kuruluşlarında mesleki faaliyetlerini sürdürmektedir. Katılımcıların çoğunluğu $(\% 58,3)$ kendi bürolarında bağımsız olarak çalışmakta olup, kalan \%41,7'lik kesim bir işverene bağlı olarak faaliyet göstermektedir.

Tablo 3. Araştırmaya Katılan Muhasebe Meslek Mensuplarının Demografik Özellikleri $(\mathrm{n}=391)$

\begin{tabular}{|c|c|c|c|c|c|}
\hline Cinsiyet & $\mathbf{f}$ & $\%$ & Mevcut iş yerindeki çalışma süresi & f & $\%$ \\
\hline Kadın & 163 & 41,7 & 1 y1ldan az & 31 & 7,9 \\
\hline Erkek & 228 & 58,3 & $1-5$ y1l aras1 & 112 & 28,6 \\
\hline Yaş & $\mathbf{f}$ & $\%$ & 6-10 y11 aras1 & 51 & 13,0 \\
\hline $25-35$ aras1 & 121 & 30,9 & $11-15$ y1l aras1 & 45 & 11,5 \\
\hline $36-45$ aras1 & 151 & 38,6 & $16-20$ y1l aras1 & 46 & 11,8 \\
\hline $46-55$ aras1 & 83 & 21,2 & 21 y1l ve üstü & 106 & 27,1 \\
\hline 56 ve üstü & 36 & 9,2 & Mesleki çalışma süresi & $\mathbf{f}$ & $\%$ \\
\hline Eğitim Durumu & $\mathbf{f}$ & $\%$ & 1 y1ldan az & - & - \\
\hline Lise & 26 & 6,6 & $1-5$ y1l aras1 & 46 & 11,8 \\
\hline Ön Lisans & 14 & 3,6 & 6-10 y11 aras1 & 46 & 11,8 \\
\hline Lisans & 290 & 74,2 & 11-15 y1l aras1 & 63 & 16,1 \\
\hline Yüksek Lisans & 61 & 15,6 & $16-20$ y1l aras1 & 67 & 17,1 \\
\hline Medeni Durum & f & $\%$ & 21 y1l ve üstü & 169 & 43,2 \\
\hline Evli & 270 & 69,1 & Çalışma Yeri & $\mathbf{f}$ & $\%$ \\
\hline Bekar & 121 & 30,9 & SMMM Bürosu & 260 & 66,5 \\
\hline Çalışma şekli & f & $\%$ & Özel Sektör Muhasebe Departmanı & 114 & 29,2 \\
\hline Bağımlı & 163 & 41,7 & Bağımsız Denetim Kuruluşu & 17 & 4,3 \\
\hline Bağımsız & 228 & 58,3 & & & \\
\hline
\end{tabular}

Tablo 4'te araştırmaya katılan muhasebe meslek mensuplarına ait tükenmişlik alt boyutlarının ortalamaları, standart sapmaları, minimum ve maksimum puan dağılımları yer almaktadir.

Tablo 4. Tükenmişlik Ölçeğinin Puan Dağılımı

\begin{tabular}{lccccc}
\hline \multirow{2}{*}{ Tükenmişlik Alt Boyutları } & $\mathbf{n}$ & $\overline{\mathbf{x}}$ & $\begin{array}{c}\text { Standart } \\
\text { sapma }\end{array}$ & Min. & Mak. \\
\cline { 2 - 6 } & 391 & 27,57 & 7,83 & 9 & 45 \\
\hline Duygusal Tükenme (DT) & 391 & 13,19 & 3,89 & 6 & 23 \\
\hline Duyarsızlaşma (D) & 391 & 28,87 & 5,15 & 17 & 39 \\
\hline Kişisel Başarı (KB) & & & &
\end{tabular}

Tablo 4’ten de görüldüğü üzere, araştırmaya katılan muhasebe meslek mensuplarının tükenmişlik düzeyi tüm alt boyutlarda ( $\mathrm{DT}=27,57>27 ; \mathrm{D}=13,19>13, \mathrm{~KB}=28,87<31)$ yüksek çıkmıştır. Dolayısıyla araştırmaya katılan muhasebe meslek mensuplarının yüksek düzeyde tükenmişlik yaşadığı söylenebilir.

Veriler normal dağılım gösterdiği için araştırmaya katılan muhasebe meslek mensuplarının tükenmişlik düzeylerinin demografik değişkenlere göre farklılık gösterip göstermediği t testi ve ANOVA testi ile ölçülmüştür. T testi, iki grup arasında istatistiksel açıdan anlamlı bir farkın olup olmadığının tespitinde kullanılırken, ikiden fazla gruplar arası 
karşılaştırmalar için $\mathrm{t}$ testi uygun olmayıp, ANOVA testi kullanılmaktadır (Coşkun vd.,2017:191). Dolayısıyla muhasebe meslek mensuplarının tükenmişlik düzeylerinin cinsiyet, medeni durum ve çalışma şekline göre farklılık gösterip göstermediği t testi ile; yaş, eğitim durumu, mevcut iş yerindeki çalışma süresi, mesleki çalışma süresi ve çalışma yerine göre farklılık gösterip göstermediği ANOVA testi ile analiz edilmiştir.

Araştırmaya katılan muhasebe meslek mensuplarının tükenmişlik düzeylerinin (duygusal tükenme, duyarsızlaşma, kişisel başarı alt boyutlarında) cinsiyete göre farklılık gösterip göstermediğini açıklayan $\mathrm{t}$ testi sonuçları Tablo 5 'te yer almaktadır.

Tablo 5. Tükenmişlik Alt Boyutları ile Cinsiyet Arasındaki Farklılık

\begin{tabular}{|c|c|c|c|c|c|c|c|}
\hline \multirow{2}{*}{$\begin{array}{l}\text { Tükenmişlik Alt } \\
\text { Boyutları }\end{array}$} & \multicolumn{7}{|c|}{ Bağımsız Örneklem T Testi } \\
\hline & Cinsiyet & $\mathbf{N}$ & $\overline{\mathbf{x}}$ & SS & sd & $\mathbf{t}$ & $\mathbf{p}$ \\
\hline \multirow{2}{*}{ Duygusal Tükenme } & Kadın & 163 & 27,6871 & 7,16776 & \multirow{2}{*}{374,981} & \multirow{2}{*}{,261 } & \multirow{2}{*}{,79 } \\
\hline & Erkek & 228 & 27,4825 & 8,28005 & & & \\
\hline \multirow{2}{*}{ Duyarsızlaşma } & Kadın & 163 & 13,5644 & 3,32041 & \multirow{2}{*}{385,594} & \multirow{2}{*}{1,671} & \multirow{2}{*}{,095 } \\
\hline & Erkek & 228 & 12,9254 & 4,23106 & & & \\
\hline \multirow{2}{*}{ Kişisel Başarı } & Kadın & 163 & 28,2393 & 4,73604 & \multirow{2}{*}{372,859} & \multirow{2}{*}{$-2,108$} & \multirow{2}{*}{,036 } \\
\hline & Erkek & 228 & 29,3246 & 5,39211 & & & \\
\hline
\end{tabular}

Tablo 5'ten de görüldüğü üzere, tükenmişlik düzeylerinin duygusal tükenme (t(390) $=, 261 ; \mathrm{p}=, 794)$ ve duyarsızlaşma $(\mathrm{t}(390)=1,671 ; \mathrm{p}=, 095)$ boyutlarında kadın ve erkek muhasebe meslek mensupları arasında istatistiksel olarak anlamlı bir fark bulunamamıştır. Ancak her iki alt boyutta da kadın muhasebeciler daha fazla tükendiklerini belirtmişlerdir. Kişisel başarı alt boyutunda ise $(\mathrm{t}(390)=, 261 ; \mathrm{p}=, 794)$ kadın muhasebe meslek mensupları erkeklere göre anlamlı düzeyde daha yoğun tükenmişlik yaşamaktadırlar.

Tablo 6. Tükenmişlik Alt Boyutları ile Yaş Arasındaki Farklılık

\begin{tabular}{llccccc}
\hline \multirow{2}{*}{ Tükenmişlik Alt Boyutları } & \multicolumn{7}{c}{ One-Way ANOVA } \\
\cline { 2 - 7 } & \multicolumn{1}{c}{ Yaş } & $\mathbf{N}$ & $\overline{\mathbf{x}}$ & $\mathbf{S S}$ & $\mathbf{F}$ & $\mathbf{p}$ \\
\hline \multirow{3}{*}{ Duygusal Tükenme } & $25-35$ & 121 & 25,9091 & 7,12507 & & \\
& $36-45$ & 151 & 29,0265 & 7,84682 & 4,025 & $\mathbf{, 0 0 8}$ \\
& $46-55$ & 83 & 27,8916 & 7,90031 & & \\
Duyarsızlaşma & $56+$ & 36 & 26,2778 & 8,81755 & & \\
& $25-35$ & 121 & 13,6033 & 3,70018 & & \\
& $36-45$ & 151 & 13,7219 & 3,92625 & 4,649 &, $\mathbf{0 0 3}$ \\
Kişisel Başarı & $46-55$ & 83 & 12,1325 & 3,57079 & & \\
& $56+$ & 36 & 13,1918 & 4,41741 & & \\
& $25-35$ & 121 & 27,5372 & 4,74525 & & \\
& $36-45$ & 151 & 30,1126 & 4,59499 & 6,772 &, $\mathbf{0 0 0}$ \\
& $46-55$ & 83 & 29,1325 & 5,44769 & & \\
\hline
\end{tabular}

Araştırmaya katılan muhasebe meslek mensuplarının tükenmişlik düzeylerinin alt boyutlarının yaşa göre farklılık gösterip göstermediğini açıklayan ANOVA testi sonuçları Tablo 6'da yer almaktadır. Buna göre, tükenmişlik düzeyinin tüm alt boyutları yaşa göre anlamlı farklılık göstermektedir $(\mathrm{p}<0,05)$. Farklılıkların hangi gruplar arasında olduğunu belirlemek amaciyla yapılan Post Hoc testleri sonucunda; duygusal tükenme boyutunda 
$(\mathrm{F}=4,025 ; \mathrm{p}=, 008) 36-45$ yaş aralığında olanların, 25-35 yaş aralığında olanlara göre daha fazla duygusal tükenme yaşadığı, kendilerini fiziksel ve duygusal açıdan daha yorgun ve yıpranmış hissettikleri tespit edilmiştir. Duyarsızlaşma boyutunda $(F=4,649 ; \mathrm{p}=, 003)$ hem 2535 yaş hem de 36-45 yaş aralığında olanların, 46-55 yaş aralı̆̆ında olanlara göre işlerine karşı daha katı, soğuk ve ilgisiz oldukları sonucuna varılmıştır. Kişisel başarı boyutunda ise $(\mathrm{F}=6,772 ; \mathrm{p}=, 000)$, yaşı $25-35$ aralığında olanlar ile yaşı 56 ve üzeri olanların istatistiksel olarak anlamlı düzeyde tükenmişlik yaşadıkları elde edilen bulgular arasındadır.

Tablo 7. Tükenmişlik Alt Boyutları ile Eğitim Durumu Arasındaki Farklılık

\begin{tabular}{|c|c|c|c|c|c|c|}
\hline \multirow[b]{2}{*}{ Tükenmişlik Alt Boyutları } & \multicolumn{6}{|c|}{ One-Way ANOVA } \\
\hline & $\begin{array}{c}\text { Eğitim } \\
\text { Durumu }\end{array}$ & $\mathbf{N}$ & $\overline{\mathbf{x}}$ & SS & $\mathbf{F}$ & $\mathbf{p}$ \\
\hline \multirow{4}{*}{ Duygusal Tükenme } & Lise & 26 & 27,0769 & 7,82265 & \multirow{4}{*}{5,619} & \multirow{4}{*}{,001 } \\
\hline & Ön Lisans & 14 & 23,7857 & 1,76193 & & \\
\hline & Lisans & 290 & 28,4379 & 8,10643 & & \\
\hline & Y.Lisans & 61 & 24,5082 & 6,23331 & & \\
\hline \multirow{4}{*}{ Duyarsızlaşma } & Lise & 26 & 12,4231 & 4,03161 & \multirow{4}{*}{,439 } & \multirow{4}{*}{,725 } \\
\hline & Ön Lisans & 14 & 13,5000 & 1,69842 & & \\
\hline & Lisans & 290 & 13,2759 & 4,11510 & & \\
\hline & Y.Lisans & 61 & 13,0492 & 2,97448 & & \\
\hline \multirow{4}{*}{ Kişisel Başarı } & Lise & 26 & 31,1154 & 5,50873 & \multirow{4}{*}{2,473} & \multirow{4}{*}{061} \\
\hline & Ön Lisans & 14 & 30,3571 & 4,66752 & & \\
\hline & Lisans & 290 & 28,5517 & 5,29795 & & \\
\hline & Y.Lisans & 61 & 29,0984 & 4,07719 & & \\
\hline
\end{tabular}

Tablo 7'de muhasebe meslek mensuplarının tükenmişlik düzeylerinin alt boyutları ile eğitim durumları arasındaki farklılıkları gösteren ANOVA testi sonuçları yer almaktadır. Buna göre, tükenmişlik düzeyinin sadece duygusal tükenme boyutu $(F=5,619 ; p=, 001)$ eğitim düzeyine göre anlamlı farklılık göstermektedir. Farklılıkların hangi gruplar arasında olduğunu belirlemek amaciyla yapılan Post Hoc testleri sonucunda; duygusal tükenme boyutunda, lisans mezunlarının yüksek lisans mezunlarına göre daha yoğun iş stresi ve daha fazla duygusal tükenme yaşadığı söylenebilir. Duyarsızlaşma $(\mathrm{F}=, 439 ; \mathrm{p}=, 725)$ ve kişisel başarı $(\mathrm{F}=2,473 ; \mathrm{p}=, 061)$ alt boyutlarında anlamlı bir farklılık saptanmasa da duyarsızlaşma boyutunda önlisans mezunları, kişisel başarıda ise lisans mezunlarının daha fazla tükendiği sonucuna ulaşılmıştır.

Tablo 8. Tükenmişlik Alt Boyutları ile Medeni Durum Arasındaki Farklılık

\begin{tabular}{|c|c|c|c|c|c|c|c|}
\hline \multirow{2}{*}{$\begin{array}{l}\text { Tükenmişlik } \\
\text { Alt Boyutları }\end{array}$} & \multicolumn{7}{|c|}{ Bağımsız Örneklem T Testi } \\
\hline & Medeni Durum & $\mathbf{N}$ & $\overline{\mathbf{x}}$ & SS & sd & $\mathbf{t}$ & $\mathbf{p}$ \\
\hline \multirow{2}{*}{ Duygusal Tükenme } & Evli & 270 & 27,0963 & 8,07389 & \multirow{2}{*}{389} & \multirow{2}{*}{$-1,784$} & \multirow{2}{*}{,075 } \\
\hline & Bekar & 121 & 28,6198 & 7,16503 & & & \\
\hline \multirow{2}{*}{ Duyarsızlaşma } & Evli & 270 & 12,9037 & 3,91617 & \multirow{2}{*}{389} & \multirow{2}{*}{$-2,201$} & \multirow{2}{*}{, 028} \\
\hline & Bekar & 121 & 13,8347 & 3,75355 & & & \\
\hline \multirow{2}{*}{ Kişisel Başarı } & Evli & 270 & 29,2296 & 5,46083 & \multirow{2}{*}{289,231} & \multirow{2}{*}{2,253} & \multirow{2}{*}{, 025} \\
\hline & Bekar & 121 & 28,0744 & 4,29373 & & & \\
\hline
\end{tabular}


Tablo 8'de yer alan ve tükenmişlik alt boyutları ile medeni durum arasında farklılık olup olmadığını gösteren $\mathrm{t}$ testi sonuçlarına göre, duygusal tükenme boyutunda (t(390) =1,784; $\mathrm{p}=, 075)$ evli ve bekar muhasebe meslek mensupları arasında istatistiksel olarak anlamlı bir fark ortaya çıkmazken, duyarsızlaşma $(\mathrm{t}(390)=-2,201 ; \mathrm{p}=, 028)$ ve kişisel başarı boyutunda $(\mathrm{t}(390)=2,253 ; \mathrm{p}=, 025)$ evli ve bekar muhasebe meslek mensupları arasinda istatistiksel olarak anlamlı bir fark ortaya çıkmıştır. Duyarsızlaşma boyutunda bekar muhasebe meslek mensuplarının evli muhasebe meslek mensuplarına göre işleri daha az dikkate almakta olduğu, kişisel başarı boyutunda ise evli muhasebe meslek mensuplarının bekar muhasebe meslek mensuplarına göre daha yüksek kişisel başarı elde ettiği görülmektedir.

Tablo 9. Tükenmişlik Alt Boyutları ile Mevcut İş Yerindeki Çalışma Süresi Arasındaki

Farklıl1k

\begin{tabular}{|c|c|c|c|c|c|c|}
\hline \multirow[b]{2}{*}{ Tükenmişlik Alt Boyutları } & \multicolumn{6}{|c|}{ One-Way ANOVA } \\
\hline & $\begin{array}{l}\text { Mevcut İşte } \\
\text { Çalış. Sür. }\end{array}$ & $\mathbf{N}$ & $\overline{\mathbf{x}}$ & SS & $\mathbf{F}$ & $\mathbf{p}$ \\
\hline \multirow{6}{*}{ Duygusal Tükenme } & 1 y1ldan az & 31 & 24,1613 & 6,38277 & \multirow{6}{*}{4,404} & \multirow{6}{*}{, 001} \\
\hline & $1-5$ y1l & 112 & 29,8304 & 6,62494 & & \\
\hline & 6-10 y1l & 51 & 27,2549 & 7,10167 & & \\
\hline & $11-15$ y1l & 45 & 24,7778 & 8,14050 & & \\
\hline & $16-20 \mathrm{y} 11$ & 46 & 27,2826 & 9,05456 & & \\
\hline & $21 \mathrm{y} 11+$ & 106 & 27,6321 & 8,38176 & & \\
\hline \multirow{6}{*}{ Duyarsızlaşma } & 1 y1ldan az & 31 & 12,4194 & 3,37416 & \multirow{6}{*}{5,456} & \multirow{6}{*}{, 000} \\
\hline & $1-5$ y1l & 112 & 14,5446 & 3,47420 & & \\
\hline & $6-10$ y1l & 51 & 13,4118 & 4,62678 & & \\
\hline & $11-15$ y1l & 45 & 11,9778 & 3,14418 & & \\
\hline & $16-20 \mathrm{y} 11$ & 46 & 11,7609 & 4,05619 & & \\
\hline & $21 \mathrm{y} 11+$ & 106 & 13,0189 & 3,86925 & & \\
\hline \multirow{6}{*}{ Kişisel Başarı } & 1 y1ldan az & 31 & 27,0968 & 2,72464 & \multirow{6}{*}{6,143} & \multirow{6}{*}{, 000} \\
\hline & $1-5 \mathrm{y} 1 \mathrm{l}$ & 112 & 27,4107 & 4,60621 & & \\
\hline & $6-10$ y1l & 51 & 29,5686 & 5,02496 & & \\
\hline & $11-15$ y1l & 45 & 31,7556 & 3,57488 & & \\
\hline & $16-20$ y1l & 46 & 29,6087 & 5,44662 & & \\
\hline & $21 \mathrm{y} 11+$ & 106 & 29,0566 & 6,05031 & & \\
\hline
\end{tabular}

Araştırmaya katılan muhasebe meslek mensuplarının tükenmişlik düzeylerinin alt boyutlarının mevcut işteki çalışma süresine göre farklılık gösterip göstermediğini açıklayan ANOVA testi sonuçları Tablo 9'da yer almaktadır. Buna göre, tükenmişlik düzeylerinin tüm alt boyutları ile mevcut işteki çalışma süresi arasında istatistiksel olarak anlamlı bir fark ortaya çıkmıştır $(\mathrm{p}<0,05)$. Farklılıkların hangi gruplar arasında olduğunu belirlemek amacıyla yapilan Post Hoc testleri sonucunda; duygusal tükenme $(\mathrm{F}=4,404 ; \mathrm{p}=, 061)$ boyutunda mevcut iş yerinde 1-5 yıl arasında çalışan muhasebe meslek mensupları, 1 yıldan az ve 11-15 yıl arasında çalışanlara göre daha fazla duygusal tükenme yaşamaktadırlar. Duyarsızlaşma $(\mathrm{F}=5,456 ; \mathrm{p}=, 000)$ boyutunda mevcut iş yerinde $1-5$ yıl arasında çalışanların, 11-15 yı1, 1620 yıl ve 21 yılın üzerinde çalışanlara göre daha fazla tükendikleri saptanmıştır. Kişisel başarı boyutunda $(\mathrm{F}=6,143 ; \mathrm{p}=, 000)$ ise, mevcut iş yerinde 11-15 yıl arası çalışanların kendilerini 1 
yıldan az ve 1-5 yıl arasında çalışanlara göre daha yüksek kişisel başarı elde ettiği sonucuna varılmıştır.

Tablo 10. Tükenmişlik Alt Boyutları ile Mesleki Çalışma Süresi Arasındaki Farklılık

\begin{tabular}{|c|c|c|c|c|c|c|}
\hline \multirow[b]{2}{*}{ Tükenmişlik Alt Boyutları } & \multicolumn{6}{|c|}{ One-Way ANOVA } \\
\hline & $\begin{array}{c}\text { Mesleki } \\
\text { Çalış. Sür. }\end{array}$ & $\mathbf{N}$ & $\overline{\mathbf{x}}$ & SS & $\mathbf{F}$ & $\mathbf{p}$ \\
\hline \multirow{5}{*}{ Duygusal Tükenme } & $1-5 \mathrm{y} 11$ & 46 & 25,9783 & 5,63911 & \multirow{5}{*}{1,373} & \multirow{5}{*}{,243 } \\
\hline & 6-10 y1l & 46 & 26,9783 & 7,36505 & & \\
\hline & $11-15$ y1l & 63 & 26,6667 & 8,34343 & & \\
\hline & $16-20 \mathrm{y} 11$ & 67 & 27,5224 & 7,26419 & & \\
\hline & $21 \mathrm{y} 11+$ & 169 & 28,5148 & 8,41067 & & \\
\hline \multirow{5}{*}{ Duyarsızlaşma } & $1-5 \mathrm{y} 11$ & 46 & 14,1739 & 3,76123 & \multirow{5}{*}{1,387} & \multirow{5}{*}{,238 } \\
\hline & 6-10 y11 & 46 & 13,5870 & 3,65499 & & \\
\hline & $11-15 \mathrm{y} 11$ & 63 & 13,3016 & 3,96613 & & \\
\hline & $16-20 \mathrm{y} 1 \mathrm{l}$ & 67 & 13,2239 & 3,14701 & & \\
\hline & $21 \mathrm{y} 11+$ & 169 & 12,7633 & 4,18226 & & \\
\hline \multirow{5}{*}{ Kişisel Başarı } & $1-5 \mathrm{y} 11$ & 46 & 25,7609 & 3,71893 & \multirow{5}{*}{5,887} & \multirow{5}{*}{,000 } \\
\hline & 6-10 y1l & 46 & 28,6957 & 4,88476 & & \\
\hline & $11-15 \mathrm{y} 1 \mathrm{l}$ & 63 & 29,0794 & 5,17843 & & \\
\hline & $16-20$ y1l & 67 & 29,6269 & 4,51206 & & \\
\hline & $21 \mathrm{y} 11+$ & 169 & 29,7870 & 5,48175 & & \\
\hline
\end{tabular}

Tablo 10'da muhasebe meslek mensuplarının tükenmişlik düzeylerinin alt boyutları ile mesleki çalışma süreleri arasındaki farklılıkları gösteren ANOVA testi sonuçları yer almaktadır. Buna göre, duygusal tükenme $(\mathrm{F}=1,373 ; \mathrm{p}=, 243)$ ve duyarsızlaşma $(\mathrm{F}=1,387$; $\mathrm{p}=$,238) alt boyutlarında anlamlı bir farklılık saptanmamıştır. Ancak duygusal tükenme boyutunda 21 yıl ve daha fazla kıdeme sahip olanlar ile duyarsızlaşma boyutunda 1-5 yıl arası kıdeme sahip olanların daha fazla tükendikleri ortaya çıkmıştır. Kişisel başarı $(\mathrm{F}=5,887$; $\mathrm{p}=, 000)$ alt boyutunda anlamlı bir farklılık saptanmıştır. Farklılıkların hangi gruplar arasında olduğunu belirlemek amacıyla yapılan Post Hoc testleri sonucunda; kişisel başarı boyutunda muhasebe mesleğinde 1-5 yıl arasında çalışanlar ile 6-10 y1l, 11-15 y1l, 16-20 yıl ve 21 yıl üzeri çalışanlar arasında istatistiksel olarak anlamlı bir fark vardır. Mesleki kıdem arttıkça çalışanların kendilerini başarılı hissettikleri saptanmıştır.

Tablo 11. Tükenmişlik Alt Boyutları ile Çalışma Yeri Arasındaki Farklılık

\begin{tabular}{|c|c|c|c|c|c|c|}
\hline \multirow{2}{*}{ Tükenmişlik Alt Boyutları } & \multicolumn{6}{|c|}{ One-Way ANOVA } \\
\hline & $\begin{array}{c}\text { Çalışma } \\
\text { Yeri } \\
\end{array}$ & $\mathbf{N}$ & $\overline{\mathbf{x}}$ & SS & $\mathbf{F}$ & $\mathbf{p}$ \\
\hline \multirow{3}{*}{ Duygusal Tükenme } & Büro & 260 & 27,5615 & 7,28409 & \multirow{3}{*}{,459 } & \multirow{3}{*}{,633 } \\
\hline & Özel Sek. & 114 & 27,8333 & 9,34673 & & \\
\hline & BDK & 17 & 25,8824 & 3,70612 & & \\
\hline \multirow{3}{*}{ Duyarsızlaşma } & Büro & 260 & 13,1577 & 3,66373 & \multirow{3}{*}{1,499} & \multirow{3}{*}{,225 } \\
\hline & Özel Sek. & 114 & 13,0351 & 4,30256 & & \\
\hline & BDK & 17 & 14,7647 & 4,14622 & & \\
\hline \multirow{3}{*}{ Kişisel Başarı } & Büro & 260 & 29,0615 & 5,43299 & \multirow{3}{*}{1,167} & \multirow{3}{*}{,312 } \\
\hline & Özel Sek. & 114 & 28,6930 & 4,43862 & & \\
\hline & BDK & 17 & 27,1765 & 5,07734 & & \\
\hline
\end{tabular}


Tablo 11'de yer alan ve tükenmişlik alt boyutları ile çalışma yeri arasında farklılık olup olmadığını gösteren ANOVA testi sonuçlarına göre, tükenmişlik alt boyutları ile meslek mensuplarının çalışma yerleri arasında istatistiksel olarak anlamlı bir fark ortaya çıkmamıştır (duygusal tükenme $(\mathrm{F}=, 459 ; \mathrm{p}=, 633)$, duyarsılaşma $(\mathrm{F}=1,499 ; \mathrm{p}=, 225)$, kişisel başarı $(\mathrm{F}=1,167 ; \mathrm{p}=, 312))$. Ancak duygusal tükenme alt boyutunda özel sektörde çalışanların, duyarsızlaşma ve kişisel başarı alt boyutunda ise bağımsız denetim kuruluşlarında çalışan muhasebe meslek mensuplarının tükenmişlik düzeylerinin daha yüksek olduğu tespit edilmiştir.

Tablo 12. Tükenmişlik Alt Boyutları ile Çalışma Şekli Arasındaki Farklılık

\begin{tabular}{|c|c|c|c|c|c|c|c|}
\hline \multirow{2}{*}{$\begin{array}{l}\text { Tükenmişlik Alt } \\
\text { Boyutları }\end{array}$} & \multicolumn{7}{|c|}{ Bağımsız Örneklem T Testi } \\
\hline & $\begin{array}{l}\text { Çalışma } \\
\text { Şekli }\end{array}$ & $\mathbf{N}$ & $\overline{\mathbf{x}}$ & SS & sd & $\mathbf{t}$ & $\mathbf{p}$ \\
\hline \multirow{2}{*}{ Duygusal Tükenme } & Bağımlı & 163 & 27,0859 & 8,39415 & \multirow{2}{*}{321,066} & \multirow{2}{*}{$-1,008$} & \multirow{2}{*}{,314 } \\
\hline & Bağımsız & 228 & 27,9123 & 7,39396 & & & \\
\hline \multirow{2}{*}{ Duyarsızlaşma } & Bağımlı & 163 & 13,2025 & 4,09028 & \multirow{2}{*}{389} & \multirow{2}{*}{,046 } & \multirow{2}{*}{,964 } \\
\hline & Bağımsız & 228 & 13,1842 & 3,74181 & & & \\
\hline \multirow{2}{*}{ Kişisel Başarı } & Bağımlı & 163 & 28,9448 & 4,66435 & \multirow{2}{*}{377,311} & \multirow{2}{*}{,242 } & \multirow{2}{*}{,809 } \\
\hline & Bağımsız & 228 & 28,8202 & 5,48110 & & & \\
\hline
\end{tabular}

Araştırmaya katılan muhasebe meslek mensuplarının tükenmişlik düzeylerinin çalışma şekline göre farklılık gösterip göstermediğini açıklayan t testi sonuçları Tablo 12'de yer almaktadır. Buna göre, duygusal tükenme $(\mathrm{t}(390)=-1,008 ; \mathrm{p}=, 314)$, duyarsızlaşma ( $\mathrm{t}(390)$ $=, 046 ; \mathrm{p}=, 964) \quad$ ve kişisel başarı $(\mathrm{t}(390)=, 242 ; \mathrm{p}=, 809)$ alt boyutlarında bağımlı ve bağımsız çalışan muhasebe meslek mensupları arasında istatistiksel olarak anlamlı bir farkın bulunmadığı ortaya çıkmıştır. Ancak duygusal tükenme ve kişisel başarı alt boyutlarında bağımsız çalışanların, duyarsızlaşma alt boyutunda ise bağımlı çalışanların daha fazla tükenmiş oldukları saptanmıştır.

\section{SONUÇ}

Tükenmişlik, süreklilik arz eden iş stresine bağlı olarak ortaya çıkan ve bireylerin duygusal olarak tükenmesine, diğer bireylere karşı katılaşmasına, başarılarının azaldığı hissine kapılmasına neden olan bir olgudur. Tükenmişlik düzeyi; yaş, cinsiyet, eğitim durumu, medeni durum gibi kişisel özelliklere göre değişebileceği gibi işin niteliği, çalışma ortamı, yoğun iş yükü, örgütsel adaletsizlik gibi çalışılan yerin sosyal ve çevresel özelliklerine göre de değişebilmektedir. Bu çalışmada Bursa SMMMO'ya kayıtlı muhasebe meslek mensuplarının tükenmişlik düzeylerini araştırmak ve tükenmişlik düzeylerinin demografik değişkenlere göre farklılık gösterip göstermediğini tespit etmek amaçlanmıştır.

Maslach Tükenmişlik Modeli'nin kullanılarak tükenmişlik düzeyinin ölçüldüğü bu çalışmada, muhasebe meslek mensuplarının yüksek düzeyde tükenmiş olduğu sonucuna varılmıştır. Muhasebe meslek mensuplarının yoğun iş yükü altında çalışmaları ve işleri yetiştirebilmek için iş stresine maruz kalmaları tükenmişlik düzeylerinin yüksek çıkmasına sebebiyet verdiği düşünülmektedir. 
Tablo 13. Muhasebe Meslek Mensuplarının Tükenmişlik Düzeylerinin Demografik Değişkenlere Göre Farklılığ

\begin{tabular}{lcccc}
\hline \multirow{2}{*}{ Demografik Özellikler } & \multicolumn{3}{c}{ Tükenmişlik Alt Boyutları } \\
\cline { 2 - 4 } & Duygusal Tükenme & Duyarsızlaşma & Kişisel Başarı \\
\hline Cinsiyet & - & - & $\checkmark$ \\
\hline Yaş & $\checkmark$ & $\checkmark$ & $\checkmark$ \\
\hline Ĕ̆itim Durumu & $\checkmark$ & - & - \\
\hline Medeni Durum & - & $\checkmark$ & $\checkmark$ \\
\hline Mevcut İş Yerindeki Çalışma Süresi & $\checkmark$ & - & $\checkmark$ \\
\hline Mesleki Çalışma Süresi & - & - & - \\
\hline Çalışma Şekli & - & - & - \\
\hline Çalışma Yeri & - & & $\checkmark$ \\
\hline
\end{tabular}

Araştırmaya katılan muhasebe meslek mensuplarının tükenmişlik düzeylerinin alt boyutlarının hangi demografik değisskenlere göre farklılık gösterdiği Tablo 13'de yer almaktadır. Buna göre, tükenmişlik alt boyutlarından sadece kişisel başarı boyutunda kadın ve erkek muhasebe meslek mensupları arasında istatistiksel olarak anlamlı bir fark ortaya çıktığı, tüm alt boyutlarda kadınların erkeklere göre daha yoğun tükenmişlik yaşadığı görülmektedir. Her ne kadar kadınların çalışma hayatına girmesiyle birlikte aile ortamındaki işler kadın ve erkek arasında bölüşülse de toplumumuzda ev işlerinin büyük çoğunluğu kadına yüklenmektedir. Hem aile hayatında hem de çalışma hayatında yoğun çalışan kadınların erkeklere göre daha fazla tükenmesi kaçınılmazdır.

Muhasebe meslek mensuplarının tükenmişlik düzeylerinin tüm alt boyutlarının yaş gruplarına göre istatistiksel olarak anlamlı farklılıklar gösterdiği tespit edilmiştir. Buna göre 36-45 yaş aralığında olanlar duygusal tükenme ve duyarsızlaşma alt boyutlarında daha çok tükenmişlik yaşarken, 25-35 yaş aralığında olanlar ile 56 yaşın üzeri olanlar kişisel başarı boyutunda daha çok tükenmişlik yaşamaktadırlar. 25-35 yaş arasındaki muhasebe meslek mensuplarının mesleklerinin ilk yıllarında başarma hırsları daha yüksek olabilmektedir. Ancak istedikleri başarıyı elde edemediklerinde bu durum onların daha fazla tükenmesine neden olabilmektedir.

Muhasebe meslek mensuplarının tükenmişlik düzeyinin sadece duygusal tükenme boyutu ile eğitim durumu arasında istatistiksel olarak anlamlı fark olduğu tespit edilmiştir. Buna göre, lisans mezunlarının yüksek lisans mezunlarına göre daha fazla duygusal tükenme yaşadığı ifade edilebilir. Medeni durum dikkate alındığında, duyarsızlaşma ve kişisel başarı boyutunda evli ve bekarlar arasında istatistiksel olarak anlamlı farkl1lıkların olduğu, bekar muhasebe meslek mensuplarının evli olanlara göre daha fazla tükendiği sonucuna ulaşılmıştır.

Çalışma sürelerine bakıldığında, mevcut iş yerinde çalışma süresi ile tükenmişlik boyutlarının tümü arasında istatistiksel olarak anlamlı fark olduğu ortaya çıkmıştır. Buna göre, duygusal tükenme ve duyarsızlaşma boyutunda 1-5 yıl arası çalışanlar daha fazla tükenme yaşarken, kişisel başarı boyutunda 1 yıldan az ve 1-5 yıl arası çalışanlar daha fazla tükenme yaşamaktadırlar. Bunun nedeni ise, yüksek umutlarla iş yerine yeni başlayan muhasebe meslek mensuplarının beklentilerinin karşılanamaması olabilir. Meslekteki çalışma süresi ile tükenmişliğin kişisel başarı boyutunda anlamlı fark bulunmuştur. Mesleki kıdem arttıkça muhasebe meslek mensuplarının kendilerini başarılı hissettikleri saptanmıştır. 
Muhasebe meslek mensuplarının tükenmişlik düzeylerinin çalışma yeri ve çalışma şekline göre ise istatistiksel olarak farklılık göstermediği de araştırma sonuçları arasında yer almaktadir.

Sonuç olarak, ülke ekonomisine önemli katkılar sağlayan muhasebe meslek mensuplarının tükenmelerine neden olan faktörlerin araştırılması ve konuyla ilgili önlemlerin alınması, iş yüklerinin azaltılması, yasal mevzuatta değişikliklere gidilmesi toplumsal ve ekonomik açıdan oldukça önemlidir.

\section{KAYNAKÇA}

Ay, Mustafa - Avşaroğlu, Selahattin (2010), "Muhasebe Çalışanlarının Mesleki Tükenmişlik, İş Doyumu ve Yaşam Doyumlarının İncelenmesi 1- Mesleki Tükenmişlik Düzeyleri”, Uluslararası İnsan Bilimleri Dergisi, Cilt 7, Sayı 1, ss. 1170-1189.

Bährer-Kohler, Sabine (2013), Burnout for Experts - Prevention in the Context of Living and Working, Bährer-Kohler, Sabine (Ed.) “Chapter 1: Introduction”, Springer, New York.

Belias, Dimitrios - Koustelios, Athanasios - Sdrolias, Labros - Koutiva, Maria - Eleni, Zournatzi (2013), “Job Burnout Greek Bank Employees: A Case Study”, International Journal of Human Resource Management and Research, Cilt 3, Sayı 2, Haziran, pp. 105-120.

Byrne, Marann - Chughtai, Aamir - Flood, Barbara - Murphy, Evelyn - Willis, Pauline (2013), "Burnout Among Accounting and Finance Academics in Ireland", International Journal of Educational Management, Cilt 27, Say1 2, pp. 127-142.

Cannon, Nathan N. - Herda, David N. (2016), “Auditors’ Organizational Commitment, Burnout, and Turnover Intention: A Replication”, Behavioral Research in Accounting, Cilt 28, Sayı 2, Güz, pp. 69-74.

Coşkun, Recai; Altunışık, Remzi \& Yıldırım, Engin (2017). Sosyal Bilimlerde Araştırma Yöntemleri SPSS Uygulamalı, Sakarya Yayıncılık, Güncellenmiş 9. Baskı, Sakarya.

Çam, Olcay "Tükenmişlik Envanterinin Geçerlilik ve Güvenilirliğinin Araştırılması”, VII. Ulusal Psikoloji Kongresi Bilimsel Çalışmaları (Hacettepe Üniversitesi, 22-25 Eylül 1992), Ed. Rüveyde Bayraktar ve İhsan Dağ, Türk Psikologlar Derneği Yayını, Ankara, 1993, ss.155-160.

Çelik, Muhsin (2016), “Tükenmişlik Yaşam Doyumu ve İş Yükü İlişkisi: Denizli’de Faaliyet Gösteren Muhasebe Meslek Mensupları Üzerinde Bir Araştırma”, Süleyman Demirel Üniversitesi İktisadi ve İdari Bilimler Dergisi, Cilt 21, Say1 4, ss. 1139-1152.

Çiftçioğlu, Aydem (2011), "Investigating Occupational Commitment and Turnover Intention Relationship with Burnout Syndrome”, Business and Economics Research Journal, Cilt 2, Sayı 3, ss. 109-119. 
Dalğar, Hüseyin - Tekşen, Ömer (2014), "Muhasebecilerin Mesleki Tükenmişlik Düzeyleri ile Rol Çelişkisi Arasındaki İlişkiyi Belirlemeye Yönelik Bir Araştırma”, Muhasebe ve Finansman Dergisi, Sayı 62, Nisan, ss. 37-54.

Demir, Özcan - Sezgin, Eray Ekin (2017), "Muhasebe Meslek Mensuplarının Tükenmişlik Düzeyleri ile Örgütsel Bağlılık Kavramı Arasındaki İlişkinin İncelenmesi: TRB1 ve TRC2 Bölgesindeki İşletmelerde Yapılan Bir Çalışma", Muhasebe ve Vergi Uygulamaları Dergisi, Cilt 10, Sayı 3, Şubat, ss. 33-54.

Deran, Ali - Beller, Beyhan (2015), "Muhasebe Meslek Mensuplarında Tükenmişlik Sendromu Üzerine Giresun İl Merkezinde Yapılan Bir Araştırma", Erciyes Üniversitesi İktisadi ve İdari Bilimler Fakültesi Dergisi, Sayı 45, Ocak-Haziran, ss. 69-93.

Doğan, Zeki - Nazlığlu, Elif Hilal (2010), "Muhasebe Meslek Mensuplarında Tükenmişlik Sendromu Üzerine Bir Araştırma", "İş, Güç" Endüstri İlişkileri ve İnsan Kaynakları Dergisi, Cilt 12, Sayı 3, Temmuz, ss. 97-116.

Eker, Melek - Anbar, Adem (2008), “Work Related Factors That Affect Burnout Among Accounting And Finance Academicians", "İş, Güç" Endüstri İlişkileri ve İnsan Kaynakları Dergisi, Cilt 10, Sayı 4, Eylül, pp. 111-37.

Ergin, Canan "Doktor ve Hemşirelerde Tükenmişlik ve Maslach Tükenmişlik Ölçeğinin Uyarlanması", VII. Ulusal Psikoloji Kongresi Bilimsel Çalışmaları (Hacettepe Üniversitesi, 22-25 Eylül 1992), Ed. Rüveyde Bayraktar ve İhsan Dağ, Türk Psikologlar Derneği Yayını, Ankara, 1993, ss.143-154.

Ersoy, Ayten - Demirel Utku, Burcu (2005), "Konaklama İşletmeleri Muhasebe Müdürlerinde Tükenmişlik Sendromu-II”, Muhasebe ve Finansman Dergisi, Sayı 27, Temmuz, ss. 38-46.

Felton, J.S. (1998), “Burnout as a Clinical Entity - Its Importance in Health Care Workers”, Occupational Medicine, Cilt 48, Sayı 4, pp. 237-250.

Fogarty, Timothy J. - Singh, Jagdip - Rhoads, Gary K. - Moore, Ronald K. (2000), "Antecedents and Consequences of Burnout in Accounting: Beyond the Role Stress Model”, Behavioral Research in Accounting, Cilt 12, pp.31-67.

Freudenberger, Herbert. J. (1974), "Staff Burn-out”, Journal of Social Issues, Say1 30, pp. 159-165.

Golembiewski, Robert T. - Munzenrider, Robert F. - Stevenson, J. G. (1986), Phases Of Burnout: Developments in Concepts and Applications, Praeger, New York.

Guthrie, Cynthia P. - Jones, Ambrose III (2012), “Job Burnout in Public Accounting: Understanding Gender Differences”, Journal of Managerial Issues, Cilt 24, Say1 4, Kış, pp. 390-411. 
Güllüce, Ali Çağlar - Kaygın, Erdoğan (2013), "Çalışanların Demografik Değişkenleri Açısından Tükenmişlik Düzeylerini Belirlemeye Yönelik Bir Araştırma”, Atatürk Üniversitesi İktisadi ve İdari Bilimler Dergisi, Cilt 27, Sayı 2, ss. 235-252.

Günay Yumuk, Gülsevim - Demiralay, Tülay (2016), “Serbest Muhasebeci ve Mali Müşavirlerin İş Stresi, Tükenmişlik Sendromu ve İş-Aile Yaşam Dengesi Arasındaki İlişkinin İncelenmesi”, Elektronik Sosyal Bilimler Dergisi, Cilt 15, Yaz, Sayı 58, ss. 917-935.

Gürbüz, Hüseyin - Karapınar, Murat (2014), "Bankacılık Sektöründe Çalışanların Tükenmişlik Düzeylerinin Maslach Kriterlerine Göre Ölçülmesi”, Uluslararası Yönetim İktisat ve İşletme Dergisi, Cilt 10, Sayı 23, ss. 267-278.

Gürel Bulgurcu, Esra Burcu - Gürel, Eymen (2015), "Muhasebe Meslek Mensuplarının Mesleki Tükenmişlik Düzeyinin Yaşam Doyumu Üzerine Etkisi: Aydın İli Örneği”, Muhasebe ve Denetime Bakış, Sayı 44, Ocak, ss. 37-47.

Hacıhasanoğlu, Tansel - Karaca, Nevran (2014), "Bağımsız Çalışan Muhasebe Meslek Mensuplarının ve Muhasebe Çalışanlarının Tükenmişlik, İş Tatmini ve Stres Düzeylerinin Belirlenmesine Yönelik Bir Alan Araştırması", Süleyman Demirel Üniversitesi İktisadi ve İdari Bilimler Dergisi, Cilt 19, Sayı 4, ss. 153-170.

Haque, Abdul - Aslam, Muhammed Shakeel (2011), "The Influence of Demographics on Job Burnout”, Far East Journal of Psychology and Business, Cilt 4, Sayı 2, Ağustos, ss. 57-72.

Herda, David N. - Lavelle, James J. (2012), “The Auditor-Audit Firm Relationship and Its Effect on Burnout and Turnover Intention”, Accounting Horizons, Cilt 26, Sayı 4, pp. 707-723.

İl, Zeliha (2018), "Muhasebe Meslek Mensuplarının Mesleki Tükenmişlik Durumlarının Araştırılması: Erzurum Ve Erzincan Uygulaması", Erzincan Binali Yıldırım Üniversitesi Sosyal Bilimler Enstitüsü Yayımlanmamış Yüksek Lisans Tezi, Erzincan.

Kalbers, Lawrence P. - Fogarty, Timothy J. (2005), “Antecedents to Internal Auditor Burnout”, Journal of Managerial Issues, Cilt 17, Sayı 1, Bahar, ss. 101-118.

Karakaş, Ayhan - Bilen, Aldulkadir (2014), "Muhasebe Meslek Mensuplarının Tükenmişlik Düzeylerinin İşgören Performansına Etkisi”, Bingöl Üniversitesi Sosyal Bilimler Enstitüsü Dergisi, Cilt 4, Sayı 8, Güz, ss. 139-154.

Karapınar, Murat - Gürbüz, Hüseyin (2015), Bankacılık Sektöründe Çalışanların Tükenmişlik Düzeylerinin Maslach ve Kopenhag Kriterlerine Göre Ölçülmesi ve Karşılaştırılması”, Eskişehir Osmangazi Üniversitesi İ̉BF Dergisi, Cilt 10, Sayı 2, Ağustos, ss. 245- 267.

Kasap, Burcu Beste - Taysı, Kemal - Canbaz, Serdar (2013), "Banka Çalışanlarında Tükenmişlik Sendromu Üzerinde Kırklareli İlinde Bir Araştırma", Organizasyon ve Yönetim Bilimleri Dergisi, Cilt 5, Sayı 1, ss. 33-46. 
Khattak, Jamshed Khan - Khan, Muhammad Aslam - Haq, Ayaz Ul - Arif, Muhammad Minhas, Amjad Ali (2011), “Occupational Stress and Burnout in Pakistan’s Banking Sector”, African Journal of Business Management, Cilt 5, Sayı 3, Şubat, pp. 810-817.

Kingori, Judika (2007), "Burnout and Auditor Work Behaviours in Tanzanian Public Accounting Firms”, Business Management Review Journal, Cilt 11, Sayı 1, pp.65-97.

Kotan, Leyla (2016), "Muhasebe Meslek Mensuplarının Tükenmişlik Düzeylerinin İncelenmesi: Van İli Örneği”, Yüzüncü Yıl Üniversitesi Sosyal Bilimler Enstitüsü Yayımlanmamış Yüksek Lisans Tezi, Van.

Larson, L. L. (2011) “Gender Differences in Internal Auditor Burnout” Internal Auditing, Cilt 26, Say1 1, pp. 11-18.

Lee, Raymond T., - Ashforth, Blake E. (1996), "A Meta-Analytic Examination of The Correlates of The Three Dimensions of Job Burnout”, Journal of Applied Psychology, Cilt 81, Sayı 2, pp. 123-133.

Maslach, Christina - Jackson, Susan E. (1981), "The Measurement of Experienced Burnout”, Journal of Occupational Bahaviour, Say1 2, pp. 99-113.

Maslach, Christina - Jackson, Susan E. (1986), "Manual for Maslach Burnout Inventory. Second Edition, Palo Alto, Consulting Pscyhologists Press, California.

Maslach, Christina (2003), "Job Burnout: New Directions in Research and Intervention”, Current Directions in Psychological Science, Cilt 12, Say1 5, Ekim, pp. 189-192.

Maslach, Christina - Schaufeli, Wilmar B. - Leiter, Michael P. (2001), "Job Burnout”, Annual Review of Psychology, Cilt 52, pp. 397-422.

Okutan, Elvan - Yıldız, Şule - Konuk, Filiz (2013), "İş Hayatında Tükenmişlik Sendromu: Finans ve Muhasebe Çalışanlarının Tükenmişlik Düzeylerinin Belirlenmesine İlişkin Bir Çalışma", Çankırı Karatekin Üniversitesi İktisadi ve İdari Bilimler Fakültesi Dergisi, Cilt 3, Say1 2, ss. 1-17.

Öz, Bülent - Çeviren, Seher Meral (2017), "Muhasebe Meslek Mensuplarında Tükenmişlik Sendromu: Mersin Örneği”, Ömer Halisdemir Üniversitesi İktisadi ve İdari Bilimler Fakültesi Dergisi, Cilt 10, Sayı 3, Temmuz, ss. 41-59.

Özkan, Azzem - Özdevecioğlu, Mahmut (2013), "The Effects of Occupational Stress on Burnout and Life Satisfaction: A Study in Accountants”, Quality and Quantity, Cilt 47, Say1 5, Ağustos, pp. 2785-2798.

Öztürk, Veli - Çil Koçyiğit, Seyhan - Çına Bal, Emine (2011), "Muhasebe Meslek Mensuplarının Mesleki Tükenmişlik Düzeyleri İle İşe Bağlllık Arasındaki İlişkiyi Belirlemeye Yönelik Bir Araştırma: Ankara İli Örneği”, Doğuş Üniversitesi Dergisi, Cilt 12, Say1 1, ss. 84-98. 
Öztürk, Veli - Koçyiğit Çil, Seyhan - Çına Bal, Emine (2009), "Muhasebe Meslek Mensuplarının Bazı Demografik Değişkenleri ile Mesleki Tükenmişlik Düzeyleri Arasındaki İlişki: Ankara İli Örneği”, Muhasebe ve Finansman Dergisi, Sayı 44, ss. 137-148.

Pines, Ayala M. - Aronson, Elliot - Kafry, Ditsa (1981), Burnout: From Tedium to Personal Growth, Free Press, New York.

Salant, Priscilla - Dillman, Don A. (1994). “How to Conduct Your Own Survey”, John Wiley \& Sons, Inc. Newyork.

Schaufeli, Wilmar B. - Greenglass, Esther R. (2001), "Introduction to Special Issue on Burnout and Health”, Psychology and Health, Cilt 16, Sayı 5, Eylül, pp. 501-510.

S1lı̆̆, Aylin (2003), "Banka Çalışanlarının Tükenmişlik Düzeylerinin Çeşitli Değişken Açısından İncelenmesi”, Anaadolu Üniversitesi Eğitim Bilimleri Enstitüsü Yayımlanmamış Yüksek Lisans Tezi, Eskişehir.

Stowe, Jamie Eggleston (2016), "A Quantitative Examination of the Relationship between Age, Gender, and Burnout in Public Accounting Professionals in a United States National Firm”, Liberty University Doctoral Study, USA.

Sweeney, John T. - Summers, Scott L. (2002), “The Effect of the Busy Season Workload on Public Accountants' Job Burnout”, Behavioral Research in Accounting, Cilt 14, pp. 223-245.

Tays1, Kemal (2012), "Muhasebe Meslek Mensuplarında Tükenmişlik Sendromu Üzerine Kırklareli İlinde Bir Araştırma", Trakya Üniversitesi Sosyal Bilimler Enstitüsü Yayımlanmamış Yüksek Lisans Tezi, Edirne.

Temelli, Fatma - Şendurur, Utku (2018), "Muhasebe Meslek Mensuplarında Tükenmişlik Sendromu: TRA1 ve TRA2 Bölgelerinde Bir Araştırma", Atatürk Üniversitesi Sosyal Bilimler Enstitüsü Dergisi, Cilt 22, Sayı 1, Mart, ss. 375-406.

Tepeli, Yusuf - Kayıhan, Burak - Kula, Ersan (2017), "Muhasebe Meslek Mensuplarında Mesleki Tükenmişlik ve İşe Bağlılık Arasındaki İlişkinin Analizi: Muğla İli Örneği”, Uluslararası Sosyal Araştırmalar Dergisi, Cilt 10, Sayı 49, Nisan, ss. 674-681.

Utami, Intiyas - Nahartyo, Ertambang (2012), “Auditors' Personality in Increasing The Burnout”, Journal of Economics, Business, and Accountancy Ventura, Cilt 16, Sayı 1, Nisan, pp. 161-170.

Uyar, Süleyman - Erdinç, Saliha Başak (2011), "Muhasebe Personelinin İş Doyumu ve Tükenmişlik Düzeyi”, Muhasebe ve Bilim Dünyası Dergisi, Cilt 13, Sayı 1, ss. 213 232.

Yanık, Ahmet - Dinçel Yanık, Güler (2016), "Muhasebe Meslek Mensupları Ve Tükenmişlik Sendromu: Bir Uygulama”, Dicle Üniversitesi Sosyal Bilimler Enstitüsü Dergisi, Sayı 16, Nisan, ss. 88-104. 